P-ISSN: 2774-4574; E-ISSN: 2774-4582

TRILOGI, 2(3), September-Desember 2021 (259-265) @2021 Lembaga Penerbitan, Penelitian, dan Pengabdian kepada Masyarakat (LP3M) Universitas Nurul Jadid Paiton Probolinggo

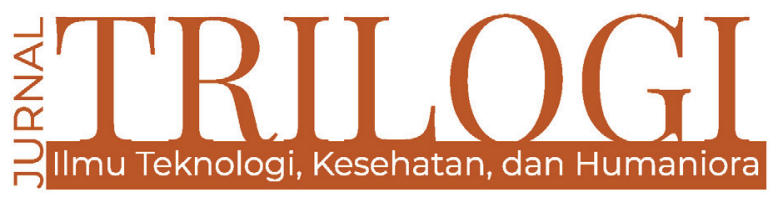

\title{
AKTIVISME DIGITAL: EFEK COVID-19 DALAM PEMBELAJARAN KAMPUS
}

\section{Zakiyah BZ}

Universitas Nurul Jadid, Probolinggo, Indonesia

bzakiyah@gmail.com

\section{Moh. Fachri}

Universitas Nurul Jadid, Probolinggo, Indonesia mohammadfahri787@gmail.com

\section{Rofi'atul Munawaroh}

Universitas Nurul Jadid, Probolinggo, Indonesia

\section{Nur Aini}

Universitas Nurul Jadid, Probolinggo, Indonesia

\section{Adilatul Himmah Fiqiyadatil Ummah}

Universitas Nurul Jadid, Probolinggo, Indonesia

\begin{abstract}
Abstrak
Penggunaan internet adalah bagian dari kehidupan kita sehari-hari. Sebagian besar dari kita menghabiskansebagian besar penggunaan kuota pada aplikasi media sosial, sepertiFacebook, Twitter, Instagram, dan YouTube sebagai media sosialsaluran . Covid-19 telah menjembatani peningkatan pesat penggunaan media sosialmedia/internet, adanya sistem pembelajaran jarak jauh (online)membuktikan bahwa pandemi ini berfokus pada pergeseran pembelajaran darikonvensional ke jarak jauh atau online (dalam jaringan). tulisannyaMetode penelitian ini menggunakan paradigma kualitatif dengan pendekatan deskriptif.Diskusi 1. Aktivisme Digital Era Covid-19 2. Dampak Covid-19 terhadapSistem Pembelajaran 3. Efek Kesehatan dari Pembelajaran Jarak Jauh atau OnlineModel (dalam jaringan). Kesimpulan: Penyebaran COVID-19 di Indonesia diawal Maret 2020. Penyebaran virus ini menimbulkan kerugian bagi banyak pihak negara, khususnya dalam bidang ekonomi. Di bidang pendidikan, COVID-19 juga mengubah model pembelajaran secara drastis; semua belajar kegiatan dilakukan secara online mulai dari sekolah dasartingkat ke tingkat universitas. Efek kesehatan perlu dipertimbangkan dalamhadir, sehingga diharapkan setiap pelaku sosial memahami danmengatasi efek penggunaan media dalam pembelajaran jarak jauh.
\end{abstract}

Keywords: aktivisme digital; covid-19; pembelajaran 


\begin{abstract}
The use of the internet is a part of our daily life. Most of us spend most of our quota usage on social media applications, such as Facebook, Twitter, Instagram, and YouTube as social media channels. Covid-19 has bridged the rapid increase in the use of social media/internet media, the existence of a distance learning system (online) proves that this pandemic is focused on shifting learning from conventional to distance or online (online). This research method uses a qualitative paradigm with a descriptive approach. Discussion 1. Digital Activism in the Covid-19 Era 2. The Impact of Covid-19 on Learning Systems 3. Health Effects of Distance Learning or Online Model (online). Conclusion: The spread of COVID-19 in Indonesia in early March 2020. The spread of this virus caused losses to many countries, especially in the economic field. In the field of education, COVID-19 has also drastically changed the learning model; All learning activities are done online starting from elementary school level to university level. Health effects need to be considered in the presence, so it is hoped that every social actor understands and overcomes the effects of using media in distance learning.
\end{abstract}

Keywords: digital activism; covid-19; learning

\section{Pendahuluan}

Penggunaan internet sudah menjadi bagian dari kehidupan kita sehari-hari. Sebagian besar dari kita menghabiskan banyak uangbagian dari penggunaan kuota pada aplikasi media sosial, seperti Facebook, Twitter, Instagram, dan YouTube sebagai saluran media sosial. Berdasarkan data dari Perhimpunan Indonesia Penyelenggara Jasa Internet (APJII), peningkatan jumlah pengguna internet di Indonesiadalam 15 tahun terakhir (2002 - 2017) mengalami peningkatan akses internet dari 4,5 juta pengguna aktif menjadi 145 juta pengguna aktif. Motif tertinggi pengguna dalam mengaksesinternet (dalam jawaban terbuka) bukanlah media online atau akses berita, tetapi media sosial dan hiburan. Dalam mengakses media sosial (Panji, 2014), ada tiga motivasi untuk anak-anak dan remaja untuk mengakses internet yaitu untuk mencari informasi, berhubungan dengan teman (lama dan baru) dan untuk hiburan. Pencarian informasi seringkali didorong oleh sekolah pekerjaan, sedangkan penggunaan media sosial dan konten hiburan didorong oleh kebutuhan pribadi.

Seiring perkembangan dunia digital yang sangat signifikan, perilakuproduksi jurnalistik telah menggeser media yang digunakan. Pergeseran ini dapat dilihat melalui laporan data "Perspektif dari Hiburan Global dan Media Outlook 2017" menyatakan bahwa laju pertumbuhan surat kabar secara global dalam lima tahun ke depan adalah minus 8,3 persen. Sedangkan untuk media massa konvensional lainnya (majalah, radio, televisi, dan buku) jugamengalami pertumbuhan minus hanya 3,4-6 persen. Di sisi lain, PwC memprediksi internet-media berbasis tumbuh 0,5 hingga 6 persen (Pujilestari, 2020).

Kompetisi berita telah mengalami perubahan yang serius, dengan diluncurkannya produk baru berupa portal media digital dan juga menggunakan akun media sosial dimendistribusikan produk berita yang beredar. Untuk memudahkan pencarian di "mesin pencari" tidak jarang menggunakan strategi digital marketing berupa penggunaan SEO, konten pemasaran, media sosial sebagai peningkatan peringkat pencarian di mesin pencari. Sementara itu, untuk meningkatkan jumlah kunjungan dan pengaruh isu yang dilakukan oleh trending topik di saluran media sosial yang sering dikunjungi oleh pengguna internet aktif (Daryanto Setiawan, 2017).

Dengan adanya fenomena baru media digital, baik perkembangan politik, Dinamika ekonomi dan sosial yang mempengaruhi masyarakat akhir-akhir ini telah membentuk suatu tatanan baruidentitas sebagai buzzer atau fanatisme dalam membela sesuatu. Penyebaran konten digitalsebagai informasi harus mencerahkan daripada terbatas pada tuduhan penghujatanantara identitas media sosial yang bersinggungan. Dalam hal ini kita dapat menggambarkan elemenyang ada pada fenomena media digital sebagai berikut (Kristiyono, 2015).

Covid-19 telah menjembatani penggunaan media sosial/internet yang meningkat pesat, Adanya sistem pembelajaran jarak jauh (online) membuktikan bahwa pandemi ini terfokus pada pembelajaran bergeser dari konvensional ke jarak jauh atau online (dalam jaringan). Oleh karena itu 
penting untuk menganalisis pengaruh penggunaan internet dalam pembelajaran di kampus (Firman dan Rahayu, 2020).

\section{Metode Penelitian}

Metode penulisan menggunakan paradigma kualitatif dengan pendekatan deskriptif. Metode deskriptif menurut Sugiono (2009) adalah metode yang bertujuan untuk menggambarkan atau memberi gambaran tentang objek yang diteliti melalui data atau sampel yang telah dikumpulkan sebagai mereka tanpa menganalisis dan membuat kesimpulan yang berlaku untuk publik. Dengan kata lain, penelitian deskriptif analitis mengambil masalah atau berfokus pada masalah sebagaimana adanya saat penelitian dilakukan, hasil penelitian yang kemudiandiolah dan dianalisis untuk menarik kesimpulan.

\section{Diskusi dan Pembahasan}

\section{Aktivisme Era Digital Covid-19}

Aktivisme digital adalah sebuah gerakan/ kegiatan dalam media digital, yang mampu mengorganisir, mengakomodasi semua kepentingan. Penggunaan media digital sebagai bentuk identitas dalam masyarakat yang memiliki banyak anggota atau pengikut. Identitas yang dimaksud adalah gambaran tentang seseorang,melalui; penampilan fisik, karakteristik, warna kulit, bahasa yang digunakan, penilaian diri, dan faktor persepsi lainnya, yang semuanya digunakan dalam mengkonstruksi budaya identitas. Identitas menurut Storr, (2010) mencakup segala sesuatu dalam diri seseorang yang dapat menyatakan secara legal dan terpercaya tentang dirinyastatusnya, nama, kepribadiannya, dan masa lalunya.

Menurut Oguri dan Gudykunst (2002), identitas merupakan hal yang penting dalam sebuah komunikasi budaya. Konsep identitas juga dapat dilihat dari aspek budaya (Tingtoomey, dalam Gudykunst, 2002) yang didefinisikan sebagai signifikan secara emosional,yang membuat seseorang melekat pada suatu hal, yang membedakannya dari yang lain sehingga lebih mudah untuk dikenali. Berdasarkan pendapat tersebut dapat kita pahami bahwa identitas dalam sosial Media dapat melahirkan bentuk-bentuk baru dalam perspektif yang berbeda tentang seseorang.
Sedangkan dalam Teori Identitas Sosial (SIT) menurut Identitas Sosial Tajfel \& TurnerTeori mengusulkan bahwa orang memiliki konsep dalam dirinya sendiri untuk bersosialisasi dan mengidentifikasidiri. Identitas pribadi melihat bahwa individu adalah makhluk yang unik, memiliki budaya, hidup dalamkelompok, dan identitas sosial mengacu pada pengetahuan anggota kelompok budaya dan berkomunikasi dengan budaya lain (Tajfel, 1974). Ciri-ciri individu yang dipengaruhi oleh kolektif dalam komunikasi individu.

Orientasi Kepribadian (personal orientation), menggambarkan bagaimana orientasi pribadi dalam berhubungan atau berkomunikasi dengan orang lain. Misalnya dalam memposting komentar tentang apa itumenjadi trend di media sosial, seperti menjalin pertemanan, mengunggah foto akan masalah, untuk berbagi berita yang menjadi isu aktual lainnya. Nilai Individu merupakan nilai-nilai kepribadian yang dimiliki individu dalam memelihara dan menjaga kepercayaan diri saat berkomunikasi. Contoh konkritnya adalah postingan yang dibuat dihalaman media sosial yang dimiliki. Dalam banyak hal, postingan yang dimaksud dapat menarik perhatianperhatian pengikut untuk menyukai apa yang membuat suatu hal menarik, baik berbagi berita atau acarayang dapat dijadikan konten untuk menarik pengunjung (Tajfel, 1981).

Konsepsi Diri (self-disclosure/ekspresi diri), menggambarkan bagaimana individu mengekspresikan diri ketika berkomunikasi dengan orang lain. Bentuk sosial yang aktifpengguna media dapat dilanggar dari beberapa aspek saham yang dibuat. Kadang pengguna aktif media digital fokus pada minat tertentu seperti traveling, kuliner, atau pariwisata. Tak jarang para pengguna media sosial mengungkapkan perasaannya demi menarik perhatian perhatian pengikutnya.

Fokus utama dalam penjabaran teori ini adalah untuk melihat bagaimana identitas adalah sesuatuyang diproduksi dalam kategori sosial (Hogg, 1993; Hogg \& Abraham, 1988; Turner 1991,dalam Gudykunst, 2002: 259). Kategori sosial dapat berupa suku, jenis kelamin, danafiliasi politik, sebagai bagian dari struktur sosial. Individu termasuk dalam sosialkategori dan pada dasarnya adalah anggota dari kategori sosial itu. Identitas menghubungkan individu denganmasyarakat melalui anggota kelompok yang mempengaruhi keyakinan individu, perilaku, dan pengetahuan dalam hubungan mereka dengan anggota kelompok sosial lainnya. Perspektif 
komunikasi menunjukkan bahwa identitas tidak dihasilkan dengan sendirinya, tetapi dihasilkan melalui proses komunikasi dengan orang lain. Prinsip utama dalam identitas muncul ketika aperubahan pesan antara dua orang. Identitas dapat dinegosiasikan, diperkuat, danberubah dalam proses komunikasi. Tujuan dari identitas ini adalah untuk membuat dan membangun komunikasi.

Pada masa pandemik co-19 identitas dibentuk secara komunal, seseorang harus dipaksa untuk memiliki sistem perencanaan yang matang untuk pemenuhan pembelajaran. Karena pembelajaran online melibatkan semua pembelajaran. Oleh karena itu, setiap individu yang identitas sosialnya pada awalnya sebatas perumusan diri, diatasi dengan pandemi sebagai rumusan pembelajaran. Sehinggapenggunaan internet semakin meningkat. Tentunya media android dan PC/komputer jugasering dalam mode On belajar. Mereka akan lebih sering menatap keduanya (Pujilestari,2020).

\section{Efek Covid-19 pada Sistem Pembelajaran}

Saat ini sedang terjadi wabah virus Corona di dunia. Virus corona itu sendiri adalah besarkeluarga virus yang menyebabkan penyakit mulai dari gejala ringan hingga berat. Ada diSetidaknya ada dua jenis virus corona yang diketahui menyebabkan penyakit yang bisa menyebabkan parahgejala. Coronavirus 2019 (COVID-19) adalah jenis penyakit baru yang belum pernah adadiidentifikasi pada manusia. Tanda dan gejala umum infeksi COVID-19 adalah gejalapenyakit pernapasan akut seperti demam, batuk, dan sesak napas. Rata-ratamasa inkubasi 5-6 hari dengan masa inkubasi terlama 14 hari (Khasanah,Pramudibyanto dan Widuroyekti, 2020).

Sejak merebaknya pandemi virus corona di Indonesia, pemerintah telahmengambil banyak langkah untuk mencegah penyebarannya. Salah satunya dengan mengeluarkan Surat Edaran Nomor 20 dari Direktorat Pendidikan Tinggi Kementerian Pendidikan dan Kebudayaan (Kemendikbud) kepada mencegah penyebaran virus corona (Covid-19) di perguruan tinggi. Melalui lingkaran ini, Kementerian Pendidikan dan Kebudayaan mengeluarkan instruksi kepada universitas untuk pembelajaran jarak jauh dan menyarankan siswa untuk belajar dari rumah (Hikmat et al., 2020).

Sistem pembelajaran jarak jauh berbasis teknologi informasi dan komunikasi.Ada beberapa jenis aplikasi yang digunakan untuk pembelajaran di masa pandemi Covid-19, disediakan oleh kelas Google, WhatsApp, Meet, Zoom, Schoology, dan sejenisnya. Aplikasi ini dapat membantu siswa dan siswi untuk menerapkan sistem pembelajaran online. Tapi pembelajaran online inimasih menemui beberapa kendala seperti gangguan sinyal, kuota internet yang tidak mencukupi danseterusnya (Firman dan Rahayu, 2020).

Pembelajaran jarak jauh juga masih kurang efektif dibandingkan pembelajaran tatap muka. Ini berhubungan denganmahasiswa yang mempelajari ilmu eksakta akan kesulitan untuk memahami ilmu eksaktakonsep dengan baik sehingga menjadi tantangan tersendiri bagi siswa yang mempelajari ilmu-ilmu tersebutkhususnya dalam bidang biologi, kimia, fisika, dan matematika (Dewi, 2020).

Tidak hanya kesulitan dalam memahami konsep, tetapi juga siswa yang seharusnya melakukan praktikum menjadi terhambat. Namun, ada beberapa universitasyang menerapkan praktikum online melalui aplikasi atau website yang tersedia. Ada juga mereka yang menerapkannya dengan menganalisis video di internet. Hal ini tentunya masih belum optimal, karena tidak bisa diamalkan secara langsung (Khasanah, Pramudibyanto dan Widuroyekti, 2020).

Selain itu, pembelajaran jarak jauh masih menimbulkan masalah bagi siswa. Sebenarnya siswamengeluh tentang materi yang belum dijelaskan sampai selesai dan malahdiberikan lebih banyak tugas. Bahkan bagi siswa yang berada di pedesaan terkadang mengalamigangguan sinyal sehingga saat dosen menjelaskan materi melalui video call tidak jelasmendengar. Begitu juga saat melakukan ujian online, masih banyak siswa yangmengalami masalah sinyal. Hal ini mengakibatkan hasil nilai ujian tidak menjadi dimaksimalkan. Adanya pembelajaran online juga mempengaruhi kuota internet yang digunakan lebih banyak danlagi. Subsidi kuota yang diberikan oleh masing-masing perguruan tinggi juga tidak mendukung aplikasidigunakan oleh dosen. Hal ini dikarenakan subsidi kuota yang diberikan mencakup aplikasi tertentuyang telah ditentukan oleh provider (Abidin, Rumansyah dan Arizona, 2020).

Pembelajaran jarak jauh tidak hanya memiliki kekurangan tetapi juga memiliki kelebihan. Keuntunganadalah siswa dapat belajar di rumah sehingga dapat menghemat waktu dan tenaga tanpa harus keluar rumahrumah. Siswa menjadi mahir dalam menggunakan teknologi informasi 
dan komunikasi. Mahasiswa dapat mempelajari materi yang diberikan oleh dosen dengan mudah bahkan dapat diakseskapanpun dan dimanapun. Mahasiswa juga dapat menjalin komunikasi yang baik dengan keluarga. I Adanya pembelajaran online juga membuat siswa terhindar dari Covid-19 sehingga dapat memutus rantai penularan virus (Jamaluddin et al., 2020).

\section{Pengaruh Kesehatan Model Pembelajaran Jarak Jauh (dalam Jaringan)}

Kegiatan pembelajaran berorientasi jarak jauh (online), mengakibatkan lebih banyak individu menatapmedia android dan $\mathrm{PC} /$ komputer yang sebenarnya jika dilakukan dalam waktu yang lama akan menyebabkanbeberapa faktor kesehatan yang negatif. Tidak banyak orang yang menyadari bahwa kesehatan itu bermacammacampermasalahan yang dapat berdampak negatif terhadap penggunaan komputer (PC) dan handphone/ponsel android. Efek jangka pendek dan paparan jangka panjang, seperti peningkatan risikokanker otak bisa muncul dari penggunaan ponsel yang berlebihan. Lebih luasnya adalah sebagai berikut: jenis penyakit yang dapat berdampak buruk bagi kesehatan akibat penggunaan media android (Sya'ban dan Riski, 2014).

\section{Gangguan Mata}

Font kecil yang ditampilkan di layar ponsel dan sinar yang terkadangterlalu terang dapat merusak mata dalam jangka panjang. Karena dua hal ini membuat mata kitabekerja lebih keras dari yang seharusnya. Bahkan, kini ada nama khusus untuk penyakit mata yang terkait hingga penggunaan ponsel atau perangkat secara umum yaitu ketegangan mata digital. Gejala inikondisi termasuk mata merah, mata kering, dan penglihatan kabur. Untuk menghindarinya, jangan menatap terlalu lamadi layar ponsel. Biarkan istirahat yang cukup sebelum menggunakannya kembali.

HP Penuh Kuman Seperti Bakteri dan Virus

Sepintas, permukaan ponsel terlihat bersih. Tapi permukaan tersebut adalah permukaan paling kotor. Banyak orang yang tidak menyadari bahwa handphone adalah barang pertama yang dipegang setelahnya berbagai kegiatan, termasuk yang kotor. Aktivitas seperti buang air kecil, berpegangan tangan di kereta sampai langsung pegang hp setelah makan, semua ini dapat membawa bakteri, virus, dan kuman berbahaya lainnya ke permukaan oftelepon selular. Karena kebiasaan ini, berbagai penyakit bisa terjadi, mulai dari diare, demam untuk muntah.

\section{Mengganggu Siklus Tidur}

Ponsel cerdas yang Anda gunakan memancarkan cahaya biru dari layar. Jika Anda menggunakan ponsel Anda sebelum tidur, paparan sinar ini menghambat produksi melatonin. Melatonin adalah hormon yang memicu kantuk. Ketika terkena cahaya biru, diyakini bahwa mekanisme otak masih siang hari. Untuk membuat Anda tetap terjaga, mekanisme di otak secara otomatis menghambat melatonin. Hal ini dapat mengganggu siklus tidur Anda. Seperti yang kita tahu, mendapatkan tidur yang cukup untuk menjaga kesehatan tubuh sangat penting.

\section{Sendi Jempol menjadi Kaku}

Jika Anda bermain ponsel terlalu lama, ibu jari Anda akan kaku dalam posisi bengkok. Jadi ketika Anda mencoba untuk meluruskannya lagi, itu terdengar cukup keras dan menyakitkan.

\section{Memicu Sakit Leher}

Saat menggunakan ponsel, posisi leher biasanya tetap bengkokposisi. Kebiasaan ini bisa menyebabkan otot leher kaku dan kram. Dalam kondisi parah,Kebiasaan membungkuk terlalu lama juga bisa menyebabkan sakit punggung, bahu, dan lengan.

\section{Memicu Risiko Tumor Otak}

Gelombang frekuensi radio yang dipancarkan oleh ponsel dapat menyebabkan kanker. Karena inigelombang dapat diserap oleh jaringan dalam tubuh yang berada di sebelah ponsel saat digunakan. SEBUAHbeberapa tahun yang lalu, lembaga penelitian kanker internasional mencatat gelombang frekuensi tinggi sebagai satu-dari hal-hal yang berpotensi karsinogenik. Dikatakan bahwa gelombang ini dapat meningkatkan risiko kanker.

\section{Gangguan Kesehatan Mental}

Hubungan antara penggunaan ponsel dan kesehatan mental sangat dipengaruhi olehmedia sosial. Beberapa penelitian mengatakan bahwa orang yang melihat unggahan orang lain secara umummerasa lebih tidak bahagia, tertekan, dan sendirian daripada teman-teman mereka. Hal ini mengacu pada kebiasaanmembandingkan hidupmu sendiri dengan orang lain, yang sulit dihindari saat membuka sosialmedia. 
Kemudian mereka menatap layar komputer yang menjadi makanan sehari-hari mereka. Namun, jikaberlama-lama di depan komputer/laptop pasti ada sisi kesehatannyaefek. Satu hal yang biasa terjadi jika terlalu lama di depan akomputer adalah (Nopriadi et al., 2019):

\section{Radiasi yang Menyebabkan Pusing}

Buku harian Semseddin Gunduz mengatakan bahwa layar komputer menyediakan banyak halradiasi. Ini menyebabkan seseorang menjadi pusing dan sakit kepala jika terus menataplayar. Masalah radiasi ini dapat dikurangi dengan memilih layar komputer yang bagus.

2. Mata Lelah Melihat Komputer

Para peneliti melihat apakah orang lebih sering berkedip di depan komputer. Ini bisamenjadi buruk, yang berarti menyebabkan mata lelah. Pada umumnya, sakit kepala terasa saat melihat sebuah objek menjadi dua, gatal, dan mata menjadi kabur.

3. Sindrom Terowongan Karpal

Ini disebabkan oleh sistem saraf yang tertekan di bawah pergelangan tangan. Gejalanya mungkin termasuk kesemutan di tangan dan jari, yang kemudian menyebabkan nyeri pergelangan tangan tiba-tiba dibahu, leher, dan bahkan bagian tubuh lainnya. Jika carpal tunnel syndrome menderita, kita tidak bisa lagi memegang benda kecil, yang menyebabkan impotensi dan ototkelemahan. Cedera karena stres berulang Cedera peregangan disebabkan oleh seringgerakan di depan komputer. Gejala biasanya terjadi dengan rasa sakit dan organpenyelewengan fungsi. Biasanya, rasa sakitnya masih terasa meskipun sudah istirahat dan ini mempengaruhibekerja, bahkan jika itu adalah pekerjaan ringan.

\section{Sakit Punggung}

Dalam sebuah buku berjudul "Fall, Sagnon, and Sow" ada pernyataan yang mengatakan bahwa komputerpengguna sering mengalami masalah dengan otot dan tulang mereka. Masalah ini sering terjadiberupa nyeri punggung. Sebuah majalah yang diterbitkan oleh kongres mahasiswa di MarmaraFakultas Kedokteran Universitas menyatakan bahwa setidaknya 94 persen pengguna komputer akanmengalami sakit punggung dalam jangka panjang.

\section{Stres dan Depresi}

Selain gangguan fisik, ada juga gangguan mental jika menggunakankomputer terlalu lama. Umumnya ini adalah stres dan depresi. Banyak faktor yang menyebabkannya. Satu salah satunya adalah sirkulasi udara, yang umumnya memiliki sirkulasi yang sangat buruk di ruang komputerkarena jendela tidak tetap terbuka.

\section{Kesimpulan}

COVID-19 menyebar di Indonesia pada awal Maret 2020. Penyebaran virus ini menyebabkan kerugian bagi banyak negara, terutama di bidang ekonomi. Di bidang pendidikan,COVID-19 juga mengubah model pembelajaran secara drastis; semua kegiatan belajar dilakukanout online mulai dari tingkat sekolah dasar hingga tingkat universitas. Penelitian ini merupakan sebuah penelitian deskriptif kualitatif yang menggambarkan kegiatan pembelajaran online setelah ditetapkannya semuakegiatan belajar dilakukan di rumah dalam mode online. Belajar dengan mode online olehmemanfaatkan aplikasi Zoom, Google Classroom, Schoology, dan Edmodo. Perkembangan Teknologi Informasi khususnya internet membuka peluang bagipengembangan layanan informasi yang lebih baik di lembaga pendidikan. Setelah wabahpandemi ke-19, pemerintah daerah mengeluarkan kebijakan di dunia pendidikan, yang untuk sementara menghilangkan pembelajaran tatap muka langsung dan digantikan dengan online pembelajaran, baik di tingkat sekolah dasar dan menengah, dan di tingkat universitas tingkat. Hal tersebut diwujudkan dalam sebuah sistem yang disebut dengan electronic university (e-University). Efek kesehatan perlu diperhatikan di masa sekarang, sehingga diharapkan setiap aktor sosial memahami dan mengatasi efek penggunaan media dalam pembelajaran jarak jauh.

\section{Daftar Pustaka}

Abidin, Z., Rumansyah and Arizona, K. (2020) Pembelajaran Online Berbasis Proyek Salah Satu Solusi Kegiatan Belajar Mengajar Di Tengah Pandemi Covid-19. Jurnal Ilmiah Profesi Pendidikan. Doi: 10.29303/Jipp. V5i1.111. 
Daryanto, S. (2017). Perkembangan Teknologi Komunikasi Dan Dampaknya Terhadap Kehidupan. Jurnal Pendidikan. Doi: 10.1155/2015/146250.

Dewi, W. A. F. (2020). Dampak Covid-19 Terhadap Implementasi Pembelajaran Daring Di Sekolah Dasar. Edukatif : Jurnal Ilmu Pendidikan.

Firman, F. And Rahayu, S. (2020). Pembelajaran Online Di Tengah Pandemi Covid-19. Indonesian Journal Of Educational Science (Ijes). Doi: 10.31605/Ijes.V2i2.659.

Hikmat Et Al. (2020). Efektivitas Pembalajaran Daring Selama Masa Pandemi Covid-19 : Sebuah Survey Online. Digital Library, Uin Sunan Gung Djati, Bandung.

Jamaluddin, D. Et Al. (2020). Pembelajaran Daring Masa Pandemik Covid-19 Pada Calon Guru : Hambatan, Solusi dan Proyeksi. Karya Tulis IImiah Uin Sunan Gunung Djjati Bandung.

Khasanah, D. R. A. U., Pramudibyanto, H. And Widuroyekti, B. (2020). Pendidikan Dalam Masa Pandemi Covid-19. Jurnal Sinestesia.

Kristiyono, J. (2015). Budaya Internet: Perkembangan Teknologi Informasi Dan Komunikasi Dalam Mendukung Penggunaan Media Di Masyarakat. Scriptura. Doi: 10.9744/Scriptura.5.1.23-30.

Ningrum, P. A., Hukom, A., and Adiwijaya S. (2020). The Potential of Poverty in the City of Palangka Raya: Study SMIs Affected Pandemic Covid 19. Budapest International Research and Critics Institute-Journal (BIRCI-Journal) (3): 1626-1634.

Nopriadi Et Al. (2019) Faktor Yang Berhubungan Dengan Kejadian Computer Vision Syndrome Pada Karyawan Bank Factors
Associated With The Incidence Of Computer Vision Syndrome In. Jurnal Mkmi.

Oguri, M. And Gudykunst, W. B. (2002). The Influence of Self Construals And Communication Styles On Sojourners' Psychological And Sociocultural Adjustment. International Journal Of Intercultural Relations. Doi: 10.1016/S0147- 1767 (02)00034-2.

Panji, A. (2014). Hasil Survei Pemakaian Internet Remaja Indonesia. Kompas.

Pujilestari, Y. (2020). Dampak Positif Pembelajaran Online Dalam Sistem Pendidikan Indonesia Pasca Pandemi Covid-19. Adalah.

Storr, V. H. (2010). The Social Construction Of The Market. Society. Doi: 10.1007/S12115010-9322-6.

Sugiono, A. (2009). Metode Penelitian Pendidikan Pendekatan Kuantitatif, Kualitatif Dan R\&D.

Sya'ban, A. R. And Riski, I. M. R. (2014). Faktor-Faktor Yang Berhubungan Dengan Gejala Kelelahan Mata (Asstenopia) Pada Karyawan Pengguna Komputer Pt.Grapari Telkomsel Kota Kendari. Proseding Seminar Bisnis \& Teknologi.

Syakur, A., Sugirin., and Widiarni. (2020). The Effectiveness of English Learning Media through Google Classroom in Higher. Britain International of Linguistics, Arts and Education (BIoLAE) Journal (2): 475-48.

Tajfel, H. (1974). Social Identity And Intergroup Behaviour. Social Science Information. Doi: 10.1177/053901847401300204.

Tajfel, H. (1981). Human Groups And Social Categories. Human Groups And Social Categories. Doi: 10.1017/S00219 320000 23336. 